\title{
Translating EU renewable energy policy for insular energy systems: Reunion Island's quest for energy autonomy
}

\author{
MATTHEW SAWATZKY \& MORITZ ALBRECHT
}

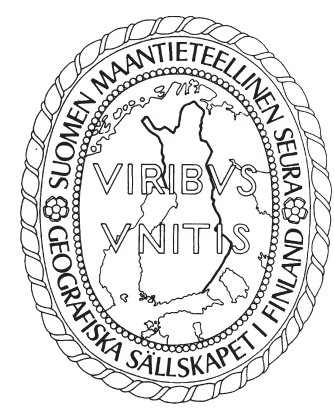

Sawatzky, Matthew \& Moritz Albrecht (2017). Translating EU renewable energy policy for insular energy systems: Reunion Island's quest for energy autonomy. Fennia 195: 2, pp. 125-141. ISSN 1798-5617.

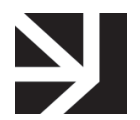

Recognition of the negative impacts of climate change has led to agreement on the need to decarbonise energy systems through the employment of renewable energy. With many national and transnational policies in place, the options available to insular energy systems (IES) differ from those of interconnected areas due to fragility in their production and distribution networks. Based on the concepts of policy mobility and translation, this study examines the interplay of EU renewable energy policy and insular governance processes aimed at achieving energy autonomy through renewable energy development. Reunion Island, a French Overseas Department and Region, is used as a case study to examine local energy governance processes, aspects that shape regional translation of national and EU policy, and the potential effects that create structures and pathways of energy transition. The study shows that Reunion Island's regional Energy Governance Committee has significant application potential as a governance tool in other IES and small islands within the EU, but that renewable energy development is restricted due to national policy measures and path dependent governance structural constraints.

Keywords: energy governance, insular energy system, policy translation, renewable energy development

Matthew Sawatzky \& Moritz Albrecht, University of Eastern Finland, Department of Geographical and Historical Studies, 80101 Joensuu, P.O. Box 111, Finland. E-mails: matthew.sawatzky@uef.fi, moritz.albrecht@uef.fi

\section{Introduction}

Following broad recognition of the negative impacts of climate change, an extensive agreement on the need to decarbonise energy systems through the development of renewable energy sources and energy efficient technologies is taking place in policy debates. While general efforts mainly focus on transnational solutions, like joint energy grids, or political projects, like the EU energy union (EC 2012), insular energy systems (IES) require different transformations. Additionally, insular communities are particularly threatened by climate change, have limited response capacities and therefore require particular attention (UNEP 2014). Generally, the development of domestic renewable energy production capacity and energy efficiency measures should increase self-sufficiency, economic value and reduce the environmental impacts of an IES (e.g. Weisser 2004; Bagci 2009; Michalena \& Angeon 2009; Marquardt 2015). We focus on the first measure and employ a relational approach to policy translation and mobility (McCann \& Ward 2012; Kortelainen \& Albrecht 2014; Peck \& Theodore 2015; 
Clarke et al. 2015) to evaluate Reunion Island's quest for energy autonomy. The island is a French Overseas Department and Region (DROM) in the Indian Ocean. Despite being part of France and framed by European Union (EU) legislation, its remote location and socio-economic composition make it an IES with many characteristics that provide valuable insights far beyond Reunion Island's role as an EU region unlike many other European IES (e.g. Duic et al. 2003; Michalena \& Angeon 2009; Oikonomon et al. 2009).

EU renewable energy policy, framed within the 202020 targets (RED 2009), insists that member states develop national policies to reach national objectives in relation to the EU's overall aims. Member states have to develop national renewable energy action plans (NREAP) which have to be updated and reported on periodically to the European Commission (EC). Reunion Island is embedded within French legislation and is part of its NREAP. While the NREAP is a binding part of the EU renewable directive (RED 2009) containing certain rules, it is translated within a nationally framed process that defines its final aims and instruments. In France, RED translation was firmly rooted in processes deriving from the 2007 Grenelle Environment Forum (Grenelle) and the events leading up to its establishment and implementation (Whiteside et al. 2010).

'Grenelle' connotes a set of broad institutional reforms, not simply imposed from above, but agreed to by major actors in civil society after an extensive process of consultation and negotiation with State representatives ... 'Grenelle' now suggests not a one-off procedure but a model to be generalised in French institutions, especially in environmental affairs (Whiteside et al. 2010, 450).

Environmental governance and policy development à la française, represented by the Grenelle, have established a kind of meso-corporatist approach favouring groups and associations over individuals (Whiteside et al. 2010, 457-458) and plays an important role in the IES transformation on Reunion Island (e.g. Praene et al. 2012). While Whiteside et al. $(2010,465)$ refrain themselves from calling 'Grenelle' a revolution, they claim that, "opening certain deliberative bodies of the French State to environmental associations changes France's political opportunity structure - and promises more change in the future." Yet, the French NREAP and renewable energy policy instruments developed following the Grenelle are not very ambitious compared to other member states' NREAPs and goals (EC 2015). However, Reunion Island's regional translation of the French NREAP, which includes the objective of energy self-sufficiency by 2030 through renewables (SRCAE 2013), shows that there are actors attempting to improve the nation's status within European environmental politics. However, Reunion Island's announcement is in line with an increasing amount of islands longing to become 100\% renewable (Duic et al. 2003) or, in Bagci's (2009) term, "zero energy islands" and further displays the heterogeneity of energy transitions within a common EU policy framework (e.g. Sarrica et al. 2016).

The governance processes that steer NREAP implementation and EU policy translation on Reunion Island largely happen in the shadows of prominent EU best-practice energy transition examples. Yet, evaluating localised translation processes on Reunion Island as part of a wider policy translation framework of interconnected loops that mobilise and mutate EU policy is noteworthy for three reasons: 1) it is an exception in a national policy environment not among the forerunners in ambitious energy transitions; 2) its insular character provides a showcase of socio-economic as well as biophysical aspects that may arise from IES solutions beyond island locations, and; 3 ) it can act as a policy laboratory to mobilise EU policy approaches to southern countries and enlarge the range of EU policy implementation to non-member states. Studies on developing fully renewable based IES on islands, including one on Reunion Island (Praene et al. 2012), tend to focus on technical aspects (e.g. Duic et al. 2003; Weisser 2004; Bagci 2009; Michalena \& Angeon 2009). While providing important information, socio-economic and cultural aspects based on local particularities, like policy design and transformation (e.g. Sovacool 2014; Sarrica et al. 2016), are treated as a side issue if at all in these studies. Another important difference between Reunion Island and many other islands is its biomass potential to reach its renewable targets (Praene et al. 2012) as opposed to a frequent focus on wind. Following, this article examines the processes of Reunion Island's IES transformation towards energy independence with a focus on the socio-spatial aspects that affect bioenergy development.

The paper begins with a brief description of the research methods and empirical materials followed by an introduction to the study's aims, the locality and its position within the EU and French 
energy policy context. Subsequently the theoretical framework employed to address the issues of policy translation, mobility and its links to path dependent versus path creative agendas of IES development is presented. Empirical results are discussed in the ensuing sections. We conclude by stressing the importance of Reunion Island's Energy Governance Committee as part of a translation loop within EU and French renewable energy policy and the possibilities for such a policy instrument to be exported to other jurisdictions.

\section{Studying renewable energy development on Reunion Island: methods, data and context}

Thematic interviews were conducted in spring 2015 on Reunion Island with 14 regional/local actors involved in policy development and bioenergy implementation (see Fig. 1). The interviewees included members of regional government agencies, energy production (both renewable and non-renewable sources) and distribution companies, as well as non-governmental organizations (NGO) involved in bioenergy, business and innovation on Reunion Island. All but two of the interviews were conducted at the interviewee's offices and ranged between 35 minutes and two hours and 50 minutes, the majority lasted for an hour and a half. Two interviews were conducted at cafés selected by the participants for the sake of their convenience. All interviews except one were conducted in French and all but one were recorded; detailed notes were taken during the unrecorded interview. Data collection also included participation in the inaugural workshop for smart grid development on Reunion Island where presentations by the French electric company EDF, the island's only electricity distributor, a university working group and a private company working to develop smart grids were given. The meeting provided an opportunity to observe the prevailing atmosphere and currents in energy

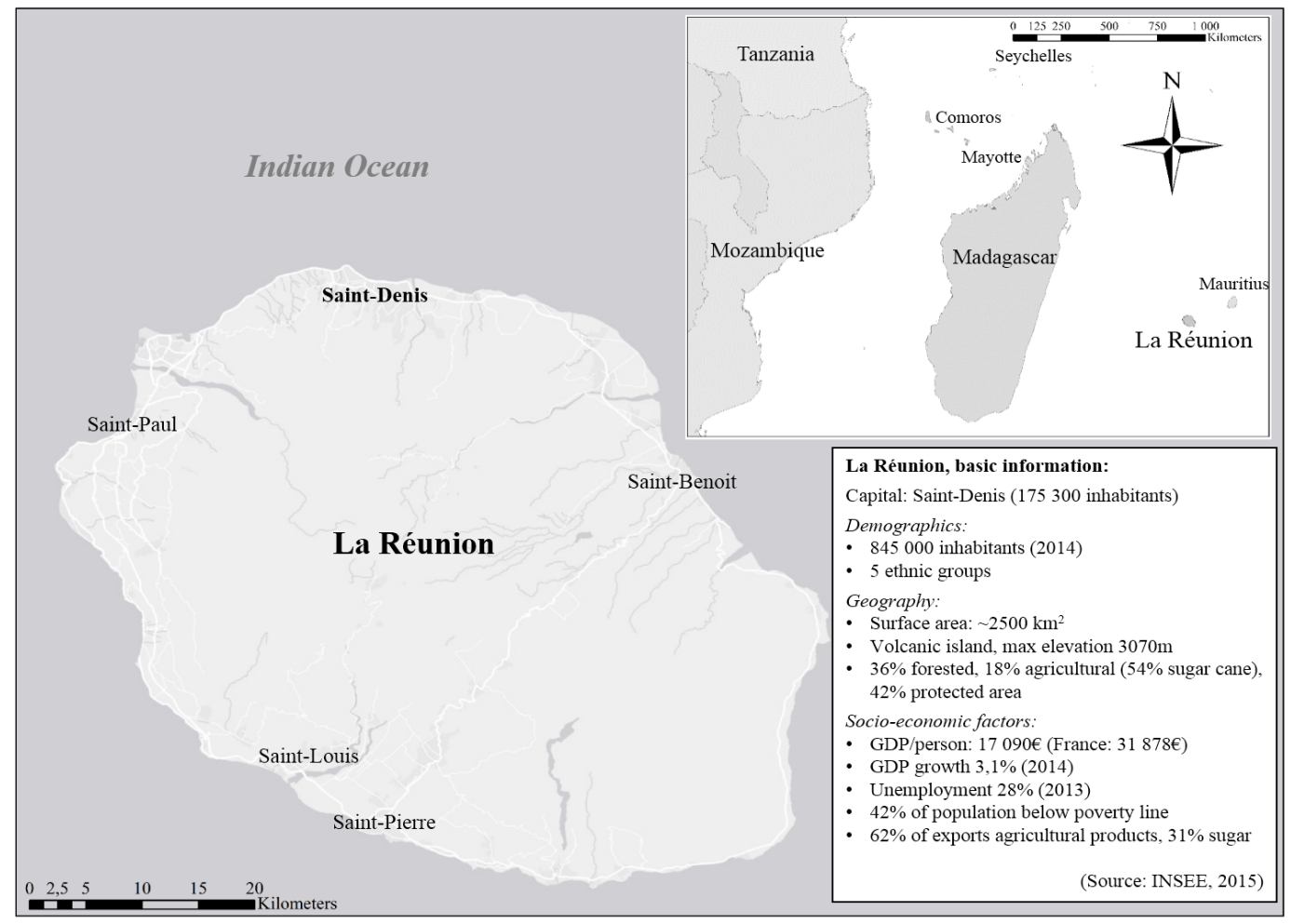

Fig. 1. Location of Reunion Island (La Réunion) and basic environmental and socio economic data (background map data: ESRI). 
governance on the island. General observations also stem from one of the author's experiences of living on Reunion Island for nearly two years.

Based on the empirical materials, the study evaluates the problematic aspects of developing renewable energy in IES and scrutinises regional EU policy translation processes embedded in a remote island context. More precisely, it asks:

1. How do governance assemblages steer policy translation and implementation on Reunion Island?

2. How have national bioenergy policies affected Reunion Island?

3. How does Reunion Island's socio-economic and biophysical environment shape its regional translation processes and governance assemblages?

In order to address these questions an introduction to the local context of Reunion Island in relation to energy production and policy is necessary. In terms of energy production and distribution, the island is different from the French mainland, which is characterised by nuclear power, a privatised distribution network and international energy connections with neighbouring countries. Reunion Island does not have any nuclear reactors, is an IES operating on a supply and demand principle since it also lacks energy storage facilities and cannot rely on neighbouring countries for support (Praene et al. 2012). Electricité de France (EDF), a former state enterprise, has a legal distribution monopoly on Reunion Island and relies primarily on imported coal to generate electricity (SRCAE 2013). During peak consumption periods EDF also uses heavy fuel oil and can turn on diesel powered turbines to meet energy demands but the number of hours per year that the latter can run are limited for environmental reasons by prefectural order. Reunion Island also has hydroelectric power, bagasse ${ }^{1}$ and $60 \%$ of households on the island are equipped with solar powered hot water tanks. Despite these substantial differences, which according to all interviewees result in much higher energy production costs, electricity is sold to consumers at the same price than on the French mainland for reasons of social equality.

Reunion Island's interest in developing renewable energy and working towards energy independence began in the early 2000s, preceding both the NREAP and the Grenelle (Table 1). Paul Vergès, then regional president, is considered as a political visionary who began developing the idea of energy autonomy by 2025 through the proliferation of renewable energies. To achieve this goal, he established a regional energy agency (ARER), now SPL Energies Réunion, as a tool to develop the island's resources and educate the public. Accordingly, Vergès can be seen as a local energy champion (Nybakk et al. 2011). Subsequent political discourse has attempted to label Reunion Island as an experimental energy centre and plays a major role in energy policy translation processes.

Following the French NREAP as a roadmap to meet the EU's 202020 targets, national objectives have been subsequently translated into regional plans. Reunion Island's plan is the Regional Schema for Climate, Air, Energy (SRCAE). Under the SRCAE $(2013,8)$, the regional government established an Energy Governance Committee (EGC) to evaluate the current energy situation and determine appropriate future directions for energy development. This committee consists of regional, local and state government actors, as well as private stakeholders, such as energy and waste companies, and the public. It is organised in a hierarchical manner with a strategic committee, secretariat, technical committee and thematic working groups.

The current objectives for the region include energy autonomy by 2030, a delay of five years from Vergès' original regional announcement, which some interviewees claimed was based purely on political will without any actual feasibility studies having been conducted. Additionally, and contrary to previous potential studies (Praene at al. 2012), all interviewees stated that Reunion Island does not currently have the ability to meet the objective due to its reliance on fossil fuels for transportation, which accounts for approximately half of the energy consumed. The SRCAE has set the objective of reducing energy consumption for transportation by $10 \%$ for 2020 by relying on technological advancements, on-going renewal of the public's cars and plans to renew part of the regional government's own fleet with electric cars powered by solar energy. Since there are currently no biofuel production facilities on the island, any biofuel to replace fossil fuel reliance would have to be imported. Paradoxically, the current regional president, Didier Robert, was elected on promises to reverse Vergès' plans to build a tramway and build a new stilted highway from La Possession to Saint Denis on the ocean instead, though this project is facing local resistance and accusations of 
Table 1. Timeframe of regional energy policy development on Reunion Island.

\begin{tabular}{|c|c|c|}
\hline Actor & Description & Role in EGC \\
\hline EDF & $\begin{array}{l}\text { World's largest electricity producer and distributor, former state } \\
\text { monopoly, privatised in 2004, maintains distribution monopoly in } \\
\text { DOMs }\end{array}$ & \multirow{6}{*}{$\begin{array}{l}\text { Strategic } \\
\text { committee }\end{array}$} \\
\hline ADEME & $\begin{array}{l}\text { French Agency for Environment and Energy Management, aids } \\
\text { companies with energy development projects }\end{array}$ & \\
\hline SIDELEC & $\begin{array}{l}\text { Inter-communal electricity union, owner of the distribution } \\
\text { network used by EDF }\end{array}$ & \\
\hline $\begin{array}{l}\text { Regional } \\
\text { Council }\end{array}$ & Represents the region, in charge of energy production on RI & \\
\hline State & Represented by the prefecture & \\
\hline $\begin{array}{l}\text { General } \\
\text { Council }\end{array}$ & $\begin{array}{l}\text { Represents the department and is in charge of waste } \\
\text { management issues on RI }\end{array}$ & \\
\hline $\begin{array}{l}\text { SPL Énergies } \\
\text { Réunion }\end{array}$ & $\begin{array}{l}\text { Regional energy agency, formerly (ARER), public education, aids } \\
\text { local governments and companies }\end{array}$ & Secretariat \\
\hline Albioma & $\begin{array}{l}\text { Multinational company, largest private electricity producer on RI } \\
\text { (solar and bagasse/coal hybrid) }\end{array}$ & \multirow{4}{*}{$\begin{array}{l}\text { Technical } \\
\text { committees }\end{array}$} \\
\hline Nexa & Regional development agency & \\
\hline Temergie & $\begin{array}{l}\text { Energy cluster for companies, supports and promotes renewable } \\
\text { energy development }\end{array}$ & \\
\hline Other Actors & Waste management, energy efficiency, producers & \\
\hline
\end{tabular}

corruption (MrMondalisation 2015; Reporterre 2015). Contrary to energy consumption for transportation, the interviewees were generally optimistic about Reunion Island's chances of reaching electrical energy independence, though not within the 2030 time frame. Following a brief description of the theoretical framework that underlies this study the remainder of this article will focus on renewable electrical energy production and governance processes.

\section{Theoretical framework: translating mobile policies}

This research is based on a relational understanding of space (Massey 2005; Murdoch 2006) where actors, places, and things interact to (re)produce the spaces we navigate on a daily basis. Similarly, governance processes and their assemblages are treated in a relational fashion (e.g. Bulkeley 2005; Albrecht 2015). Kortelainen and Albrecht $(2014,144)$ state that governance is "a process which generates, transports and implements various norms, incentives and other means seeking to influence people's ways of acting and thinking." Thus, governance is a multi-stakeholder affair where actors, both proximate and distant, may reach across time and space to influence the actions of others. Supra-national or national policies aiming at lower-level implementation, such as RED, the Grenelle laws, or international climate agreements, are prime examples of such governance processes. While they aim to create a distantiated authority based on common targets, their framing as de-centred approaches open to negotiation (Allen 2011) provides a breeding ground for a variety of governance assemblages that tie in a multiplicity of relations and affect the local implementation/ direction of policy models. 
Therefore, this study follows the concepts of policy mobility and mutation (e.g. Peck 2011; McCann \& Ward 2012; McCann 2013; Peck \& Theodore 2015), which focus on the various processes shaping mobile policies in the continuous spaces between design and implementation elsewhere, but also evaluate the mutation processes that appear along the way when policies and governmental ideas are subject to translation processes. The focus on policy translation through assemblages moves beyond the positivist concept of policy transfer with its linear processes (e.g. Dolowitz \& Marsh 1996, 2000) and offers critical ways to understand the relational processes of mobile policies (e.g. Clarke et al. 2015; Peck \& Theodore 2015; Albrecht 2017a). To evaluate relational assemblages in relation to mobile policies in spatially differentiated, yet possibly linked localities within the governance processes of mobility and mutation, Kortelainen and Albrecht's (2014) concept of "translation loops" is useful. Translation loops are "forums in which actors are enlisted and devices developed to design, operationalize, materialize" but also to contest standards or principles of mobile policies (ibid., 147). Hence, similar to Clarke and his colleagues' (2015) understanding, this is a relational multi-sited and multi-actored conceptualisation which goes beyond institutional constraints aside it discussing mobile policies designed for a multi-level policy structure. This accounts for the regional implementation and translation of EU and national energy policy on Reunion Island, and the applicability of IES policy models in different locations with varying socioeconomic framework conditions.

The ambitious aims of Reunion Island as a translation loop of renewable energy policy is conceptually interesting for governance processes in two ways. First, regarding the translation of mobile supra-national and national policies to be implemented on the island, it points out the multiplicity of such policies due to their translations in various spaces (Clarke et al. 2015). Second, assemblages of policy translation formed around regional actors and their rationalities (in a Foucauldian sense) contribute to the relational (re)production of governance assemblages in the translation loop itself (Albrecht 2015, 2017a).

Policy mobility, mutation and translation are influenced by path dependency but simultaneously support path creation (Garud et al. 2010). While processes of policy mobility and translation are not path-dependent regimes in themselves (Clarke et al. 2015), actors and their rationalities are part of translating assemblages that are influenced by path-dependent aspects rooted in the socio-spatial characteristics of their locality or institution. Definitions of path dependency generally include the idea that, "[o]utcomes at a critical juncture trigger feedback mechanisms that reinforce the recurrence of a particular pattern into the future" (Pierson \& Skocpol 2002, 700). It is about reinforcing that which already exists and may limit or remove future alternatives. Garud, Kumaraswamy, and Karnøe (2010) differentiate path dependence from path creation, an emergent process, by focusing on the agency of actors and emphasising the ability of actors to influence processes. Ontologically speaking, we do not see path dependency and creation as separate processes but as the extremities of a continuum that exist within relational assemblages. Furthermore, we are interested in the relationships between actors in an assemblage and how their choices result in path dependencies or path creation. It should also be noted that innovation may occur within both path creation processes and path dependent processes, though there may be differences in the results, such as the development of radical or incremental innovations. By portraying the role of Reunion Island as a translation loop within policy mutation processes, the following chapters provide empirical evidence of the inner workings of path dependent and creative assemblages that guide the processes of IES renewable energy governance in relation to local, national and transnational trajectories and policy translations.

\section{Energy governance assemblages and national policy}

Before describing current governance aspects an earlier policy translation process on Reunion Island requires attention as it is closely related to the translation processes entailed in RED: the Grenelle (Table 1). The Grenelle was a French national assemblage in 2007. Its five stages consisted of the establishment of six thematic working groups, public consultation, negotiations and decisions, operational implementation and legislative implementation (Ministère 2012). While the process was 
heavily criticised by environmental NGOs and the French political Left, it was a novel approach in which opposing parties, including ENGOs, industry members, trade unions and different levels of governments sat at that same table to openly discuss environmental issues. It also led to the creation of two different laws (Grenelle I in 2009 and Grenelle II in 2010).

As a governance assemblage, the Grenelle took place in a limited time span with fixed objectives. The process began in July 2007 and working group recommendations, public consultation and decisions were made by the end of October. The implementation phase and legislative adoption lasted from December 2007 to October 2008. Three years after it began, there was still a notable lack of concrete measures in France, and the most notable achievement of the Grenelle was the recognition of ENGOs at state-level governance and an open format for actors (Garric 2010). However, regional translation of the Grenelle fixed Reunion Island's objective for energy autonomy by 2030 in national law (Grenelle de l'environnement article 56) and created a regional version of the policy: GERRI.

GERRI was the regional form of the Grenelle on Reunion Island (Ministère 2009). It began in 2008 when national, regional and local governments formed a public interest group with industry members to develop renewable energy on the island. In doing so, the actors involved in GERRI focused on innovation and experimentation in the development process. Solar energy was the primary choice of development and this corresponded to national programs which obliged electricity distributors to purchase electricity from renewable sources first and producers were given 20-year contracts with an extremely high guaranteed price. This combination provoked an explosion of solar power development on Reunion Island in the late 2000s. Additionally, following Reunion Island's self-proclaimed aims as an experimental centre, GERRI established a focus on marine energy, an innovative but risky area of development given the island's location in the tropics and regular cyclonic activity. In total GERRI participated in the launching of 150 projects and ended in 2013 when the region ceased funding (Linfo 2013).

Four important aspects concerning energy governance on Reunion Island exist within these two assemblages. First, while they are both heralded as open processes, the role of the public was limited. The Grenelle included public consultations and "reached" 30,000 participants nationally, but it occurred during a three-week period in which proposed actions were presented as opposed to receiving public input first. Regionally, documents concerning GERRI make no mention of public participation beyond industrial and commercial actors (Ministère 2009). Second, both assemblages operated for a fixed time period. Third, they aimed to reinforce the position of Reunion Island as a place of innovation and experimentation (Praene et al. 2012), an ideology that entails a great deal of risk for an isolated location with limited regional resources and infrastructure. Finally, while they remain important aspects of current renewable energy policy translation processes, the Grenelle and GERRI initially represented national and regional translations of the EU's desire for a comprehensive environmental policy, which took effect in 2005 and was framed by greater environmental awareness in general. Accordingly, current French national and Reunion Island's regional translation of EU energy policy and the resulting energy governance can be interpreted as attempts to foster path creation with mixed results.

\section{Energy Governance Committee}

The Energy Governance Committee (EGC) is the main policy tool for Reunion Island's energy transformation. According to one interviewee, the EGC is based on an idea from the island's tourism industry, which involved actors in the decision-making process and used their expertise to evaluate existing infrastructure and needs to guide development. While these structures are hierarchical, they are also inclusive, drawing inspiration from the Grenelle and GERRI.

The EGC is a tri-level governance structure funded by the French national government and Reunion Island's regional government (Table 2). The strategic committee sits atop while the secretariat organises and coordinates the activities of seven technical committees. The technical committees act as operational groups for financial studies, renewable energies, energy efficiency, energy precariousness, climate/urban planning/transportation, innovation and training, and international cooperation. The structure is largely a copy of the Grenelle and GERRI, but one 
significant difference is that technical committee heads come from either public or private institutions or companies. This aspect enables regional actors to have a greater say on what information is presented to decision makers as it potentially shifts the balance of power in governance, increasing regional actors' (both public and private) reach and their potential to influence policy translation and mutation processes framed though their own rationalities.

Van Waarden and Oosterwijk (2006, 443-444) claim that innovative systems, like the EGC, are governed by the six I's (institutes; interdependencies and interlinkages; interests; ideas, information, knowledge, competencies; incentives; and institutions), which may either contribute to or remove path dependencies at various scales. In this regard the interviews reveal a rather positive picture of the EGC. The regional government has received delegations from other French departments, including other DROMs, who were interested in learning more about the EGC in order to develop similar structures. Theoretically, the inclusion of actors from different parts of the energy sector in the decision making process facilitates the exchange of knowledge and ideas, relationship building, technological development and innovation. It also allows for those in charge, as well as others, to hear first-hand accounts of the challenges facing economic actors. These exchanges offer an opportunity for actors involved in implementing national and supra-national policies and objectives to influence the direction and extent to which policies are translated or developed. We say theoretically because assemblages involve power relations and the interviewees made it clear that those involved in the EGC were first and foremost representatives of individual companies who do not disclose everything. The interviewees felt that this level of secrecy was normal and not unhealthy; and the same could be said of virtually any governance process. However, with trust playing an important role in IES implementation processes (Michalena \& Angeon 2009) this could become problematic.

The inherent hierarchy within the EGC warrants further scrutiny. The description of the EGC and its activities in the $\operatorname{SRCAE}(2013,8-10)$ as well as the interviewees' descriptions of it reveal some discrepancies. The EGC was established for two main purposes: 1) to assess Reunion Island's current state of affairs (both quantitatively and qualitatively) in terms of climate, air, and energy, and 2) to share that information with actors and the public to define objectives and a direction for development (SRCAE 2013, 8). The objectives of knowledge production, distribution and selection of preferential pathways for implementation locate the EGC at the core of the island's policy translation and transformation processes of its energy system.

The inclusion of actors and the public is an on-going process in environmental governance (e.g. Cohen \& McCarthy 2015) and has been coupled with improved renewable energy development and environmental improvement for IES (Michalena \& Angeon 2009). Frequently, the opening up of governance processes includes periodic consultation meetings with stakeholders and the public; yet, in many instances these efforts are unsuccessful as decision makers either fail to fully take into account the opinions expressed or opinions counter the prevailing ideals of improved environmental performance (see Albrecht 2010; Sawatzky 2013). The EGC's structure differs from many others in that it is a formalised inclusion of concerned actors with clearly defined roles in a continual process. The technical committees have dual functions in the EGC. They act as a formal reception area to

Table 2. Key actors within Reunion Island's EGC framework.

Timeframe 2000-2016

\begin{tabular}{|c|c|c|c|c|}
\hline $\begin{array}{l}\text { Regional } \\
\text { Declaration } \\
2000\end{array}$ & $\begin{array}{c}\text { Grenelle } \\
2007\end{array}$ & $\begin{array}{c}\text { GERRI } \\
2008-2013\end{array}$ & $\begin{array}{l}\text { NREAP } \\
2009\end{array}$ & $\begin{array}{c}\text { SRCEA } \\
2013\end{array}$ \\
\hline
\end{tabular}


translate mobile policies of EU and national origin into regional objectives, while simultaneously generating and providing information for decision makers on the strategic committee at the regional level. Thus, they have continuous opportunities to influence policy development and guide translation processes within the wider regionally linked assemblage. The strategic level committee functions similarly, receiving national and supra-national objectives and policies and, in turn, providing information from the regional level in order to influence existing and future policies. Overall, the EGC has managed to include the main regional energy actors in a meaningful way while functioning as a fulcrum between regional actors and the national government.

\section{Democratic challenges in the EGC}

The idea of establishing political goals in conjunction with private companies in the EGC entails risks and challenges for democratic ideals. All of the interviewees evoked the privileged status of Electricité de France (EDF) as the only electricity distributor on Reunion Island and its role as the only private company on the EGC's strategic committee. The interviewees agreed that it was necessary to include EDF at the decision-making level due to its distribution monopoly, but the company's goals may diverge from those of other actors in the EGC and renewable energy development in general. EDF has invested heavily in nuclear power around the world and while there are no nuclear reactors on the island, their investments and expertise in nuclear energy influence their perspective on energy governance objectives at the national level and consequently affects regional energy development.

Two lines of thought regarding EDF's role on Reunion Island and the EGC appeared in the interviews. First, EDF is seen as a public service provider, which benefits the EGC and the public. Most interviewees, referring to the island's IES, stated that it is easier to have a single, knowledgeable distributor and supported EDF's role. However, there are currently large electricity producers with the potential to operate a distribution network on Reunion Island and a few of the interviewees stated that their companies would like to become distributors but are legally excluded from distribution (La P'tite Gazette 2004). Their desire to become electricity distributors is an expression of path creation within the governance assemblage while the policy to maintain EDF's distribution monopoly is a path dependent aspect of it. Both elements help shape regional policy translation processes.

The second line of thought is more critical of EDF's role in the EGC. Some of the interviewees stated that EDF's role on the strategic committee was a necessary evil because it is the only actor with the pertinent knowledge and technical abilities to run an IES distribution network. However, many actors cited EDF's lethargy or lack of forthrightness on specific issues that would put the company at a competitive disadvantage on the open market, though this was still at an acceptable level for most individuals. One interviewee raised a more important issue when discussing EDF's role in selecting a development direction for Reunion Island. This individual claimed that renewable energy development should focus on individual or small-scale collective energy systems, ranging from the household or building level up to the neighbourhood level through the use of storage systems for solar or wind power. Even though the interviewee admitted that decentralising production and distribution to this level would be costly, he felt that the most prohibitive feature of developing in this manner would be the removal of EDF's clientele and overcoming the company's influence on the EGC. Other actors, however, stated that, while EDF was on the strategic committee, political representatives made the final decisions.

\section{French national policy and its translation framework on Reunion Island}

France is known for the particularly strong centralisation of its governance culture. This can be linked to an ideology of equality but, at times, it fails to acknowledge local specificities, which are necessary to understand bioenergy governance and development (Albrecht 2015, 2017; Albrecht \& Trishkin 2017). The French law on modernising its electricity service (Loi $n^{\circ} 2000-108$, Article 102000 ), stipulates that distributors must purchase electricity produced from renewable sources before energy produced from non-renewables sources whenever available ${ }^{2}$. As an effort to break the nation's dependency on fossil fuels and nuclear energy, this clearly represents an act of path creation. However, in Reunion 
Island's translation it only applies to those forms of renewable energy which provide a stable output, like bagasse, which is readily available after the sugar cane harvest. For other renewable forms of energy, like solar and wind, EDF's obligation to purchase is limited to $30 \%$ of demand based on their intermittent nature and the fact that the electrical grid is an IES with a single distributor, no external connections and limited storage facilities, which results in system fragility (54 power outages in 2014).

A representative from EDF stated that while solar production on the island is capable of supplying more than $30 \%$ of the daytime requirements, when clouds pass over the solar panels and reduce their production there is not enough warning time to switch over to coal or diesel fired power plants and blackouts may occur. Nevertheless, there are PV potential forecasting possibilities for Reunion Island (Diagne et al. 2012) providing enough time to start a diesel based power plant. The exception to this practice on Reunion Island is intermittent power sources with storage facilities, but these are currently expensive to develop and EDF does not have to pay a premium for stored renewable energy, which means that companies are reluctant to invest in such technology. There is currently only one solar facility on the island with a storage capacity of 9MW (Akuo 2015).

The fragility of the island's electricity network and the policy translation establishing a maximum threshold of $30 \%$ of intermittent renewable energy are consequently hindering energy independence on the island (Praene et al. 2012), the achievement of national objectives and the creation of a new energy path. But while the $30 \%$ policy is promoted as a protection mechanism to ensure electricity supply, the interviewees were not sure if it was correct. A representative from EDF explained that it would be good to raise the percentage through technological advancements, like better warning systems for intermittent power sources which would enable EDF to increase its output in a more timely manner. Other actors claimed that it was a case of regulatory capture (e.g. Engstrom 2012) where the threshold was purposefully established at a lower than possible level for economic reasons and that EDF was able to accomplish this because of its political influence and distribution monopoly.

In accordance with France's NREAP, the regional plan has emphasised the importance of biomass in achieving the island's energy objectives (SRCAE 2013, 66). Most of the actors interviewed in this study agreed that if EU, national and regional political objectives are to be met by 2020, biomass must play a critical role. While bioenergy development and environmental protection are supposed to support one another, related legislation may have negative effects (e.g. food vs. fuel debate). Such effects are amplified on Reunion Island due to its small size, dense population and rapid urbanisation, all of which are common aspects among many IES. Albioma, a private company and the main bioenergy player on Reunion Island, supplies approximately $10 \%$ of the island's households with biomass based electricity and plans to increase its production (Albioma 2015). Their current supply comes solely from bagasse and the interviews made it clear that Reunion Island has a limited amount of biomass due to its small area, dense and growing population, vertiginous topography and poor road network. Compounding these effects are a national park and UNESCO world heritage site. The park covers $40 \%$ of the island and harvesting vegetation is forbidden (Parc National de La Réunion 2007).

Despite this, the $\operatorname{SRCAE}(2013,61-63)$ sites three possibilities for increasing biomass energy production: the development of more fibrous sugar cane (see also Sabatier et al. 2015), increasing the amount of hectares cultivated and locating other fibre sources. Two potential biomass sources were identified in interviews: invasive tree and vegetation species within the national park and biomass from other countries. The former would require special permission from the appropriate authorities and falls in line with current environmental protection trends to remove non-endemic species (Sugiura et al. 2009), but would remain a short-term solution. The interviewees claimed that importing biomass from other countries provides a greater source of energy, though not before calculating the carbon footprint of importing biomass and ensuring that it does not contribute to deforestation or food shortages elsewhere.

A second national policy intended for environmental protection hindering renewable energy development on Reunion Island is France's Coastal Law (1986, Loi $\left.n^{\circ} 86-2\right)^{3}$. This urban planning law was introduced to protect coastal nature and preserve sites, landscapes and cultural and natural heritage from quickly urbanising areas on the coast. It obliges coastal communities to develop in a 
continuous manner with the existing urban area and forbids the construction of wind turbines over 50 metres tall within 500 metres from any building. On the island, where the majority of the population lives along the coast, this has also resulted in a failure to develop wind energy (CMS 2014).

Another national policy aspect challenging renewable energy development on Reunion Island identified by interviewees is the Regulatory Commission on Energy (CRE). Established in 2000, the CRE acts as an independent regulatory body for electricity and gas in France and funding demands go through the Minister of Energy and Minister of Finance. It consists of two levels: a board called the commission and a committee for disputes and sanctions; two out of six current commission members have worked for EDF. The commission's tasks include, among others, setting the purchase price of electricity from renewable sources for EDF (Article 314-4 Code of energy), advising authorities on the construction of private networks (Article L343-1 of the Code of energy), and it "ensures the realisation of necessary investments for the proper development of networks (Article L 321-6 of the Code of energy and Article 431-6 of the Code of Energy)" (CRE 2015).

According to the interviewees, the CRE influences renewable energy development on Reunion Island in three main ways. First, by establishing the prices that EDF has to pay for electricity produced from renewable sources, the CRE directly impacts the economic feasibility of projects and, consequently, the willingness of companies to invest in new projects. Second, by advising authorities on the development of projects with private networks, the CRE influences the direction of energy development. For example, if it refuses to fund projects that focus on the apartment building or neighbourhood level for financial reasons, the CRE could end up favouring large-scale projects, thus limiting the type of energy actors involved in renewable energy development. Finally, the CRE is responsible for the tendering process for new energy projects via its responsibility to ensure network development. This means that it decides when and how new projects will be developed and, according to the interviewees, there have not been enough calls for projects in the last few years. Thus, the CRE provides another frame in which local translation processes take place and affects the pathways chosen by actors.

\section{Reunion Island as a translation loop of EU and French energy policy}

Politicians and bioenergy actors on Reunion Island have referred to themselves as innovators for nearly a decade and have built a reputation in France as being a niche for experimental projects (e.g. Ministère 2009; Praene et al. 2012). As stated above, it was during the Vergès era that the quest for energy autonomy really began with a political discourse on renewable energy and innovation, as well as the development of political structures and assemblages, like GERRI. However, innovation and experimentation have had questionable impacts on local life. The brief solar power boom of the late 2000 s relied on policies designed to develop but not sustain the industry. In 2008, the French national government realised that the industry's exponential growth was economically unsustainable and placed a moratorium on new projects over $100 \mathrm{MW}$ and the price/kWh fell to $0.35 € / \mathrm{kWh}$ in 2010 and $0.117 € / \mathrm{kWh}$ in 2011 (SRCAE 2013, 57) causing the blossoming industry to stagnate. More importantly, French banks have become hesitant to support projects without the 20-year guarantee at the advantageous price previously afforded by the policy. It should also be noted that these activities were hardly innovative on the global scale; they were an application of existing technology.

The solar boom did however awaken a desire to innovate and attract other renewable energy investors to the island, which remain core aspects of the present energy governance assemblage. Reunion Island has succeeded in creating an experimental niche for marine energy projects. Some of the noteworthy ones include sea water air conditioning, the first large scale urban application of the technology in the world (Saudemont 2015), a prototype adapted to the island's swell force for underwater wave energy (washed out during a cyclone, Royer 2015), and ocean thermal energy conversion (DCNS 2014). While experiments for ocean thermal energy conversion were successful, the company decided to build a full-scale project in Martinique where conditions are more favourable. These projects illustrate that policy translations intending to turn Reunion Island into an experimental energy place have been partially successful, but they also highlight the technological 
and social risks associated with innovation and the possible lack of local returns. So while the island has managed to attract a significant number of innovative actors, hydroelectricity, biomass and solar power are currently driving renewable energy development.

\section{Discussion}

Reunion Island's path towards energy independence has taken a unique direction. The geographic mix of being an EU outermost region, a French DROM and a tropical island have led politicians to translate EU and French energy policy into more ambitious goals than the rest of the nation. Yet, since institutional translation is only one aspect of policy translation through (regional) assemblages, current development has fallen short of these aims. For instance, as in many EU localities, it has been unable to effectively reduce its energy consumption for transportation. However, the island has the potential to achieve its objectives pertaining to electricity production and consumption, in part through improving and decentralising participatory governance structures.

We believe that the EGC is a partial success and understand it as an attempt at path creation. In spite of EDF's monopoly and its role on the EGC's strategic committee, both of which we interpret as path dependent aspects that may no longer be required, the EGC represents a new model of energy governance attempting to break away from the previous French model of top-down, centralised governance. Its hierarchical structure, which is perhaps a necessity for this type of governance given what is at stake, has found a way to meaningfully include regional actors and given them a chance to influence regional translations of national and supra-national energy policies and thereby influence the future direction of French and EU renewable governance processes.

As part of the wider policy translation loop, the EGC may also be seen as a governance tool with the potential to be exported to other jurisdictions. An interviewee from the regional government mentioned how other French departments had already visited or called to gather information about the structure to develop their own committee. However, the EGC has taken shape in a very specific relational context and the region benefits from France's solid democratic system, ideology and structure. The national economy, which has been categorized as a state-supported hierarchy (Hage 2006, 468) and as a type of bricolage somewhere between a liberal market economy and a coordinated market economy where large firms have an increasing amount of power but still rely on firm-level negotiations (Culpepper 2006), must also be taken into account. As a member of the EU, there are subsidies available to actors not existing in most non-EU insular settings. Additionally, EDF's experience and monopoly facilitate governance by providing the necessary knowledge and expertise in a single entity, even though its role at the strategic level is questionable. Consequently, other French DROMs are the most likely export destinations for the EGC model because EDF has guarded its monopoly there as well, and French national policies and objectives apply.

Nevertheless, monopoly energy providers are rather common in IES and (inter-)national donor institutions also fund sustainable development in island states and communities (e.g. Marquardt 2015). This gives the EGC wider applicability to become an important institutionalised actor within the wider assemblage that reproduces Reunion Island as a translation loop. We believe that the system is most readily exportable to areas that have an IES and democracy, in addition to political and financial stability as it is based on democratic principles. It is important that governments choosing to implement a similar energy governance model are familiar with the give and take required. If not, the EGC could easily turn into a rhetorical instrument that fails to improve participation. Political stability is another prerequisite for the EGC model because stability has been shown to aid renewable energy governance (e.g. Blumer et al. 2013). Without the financial stability offered by Reunion Island's regional, national and EU context, the EGC model would flounder as smaller companies may not be able to afford the time to attend meetings and give input, leaving only the most economically viable companies to take over the political agenda and potentially failing to address niche markets.

Two potential problems for the EGC are the role of EDF on the strategic committee and poor public integration. The importance of EDF in the EGC is unquestionable, though its role at the decision-making level is already showing signs of becoming problematic. Whether or not France will 
one day privatise the distribution network of DROMs is an important issue, one that will certainly influence EU energy policy translation in the future. Public input and involvement in the EGC is a second potential source of problems as their involvement has been rather limited and individuals are practically excluded in public consultation hearings. This supports Whiteside, Boy and Bourgs's (2010) findings concerning the meso-corporatist character of French environmental governance. This will need to be improved for the EGC to continue in a meaningful way and in order to allow wider, public rationalities into policy translation processes.

Issues of policy translation have both hindered and helped Reunion Island's renewable energy development. French and supra-national environmental policies have unintentionally created potential obstacles for renewable energy development in the form of a national park and UNESCO world heritage site, as well as a reliance on the CRE for energy production and network development. The former is simply an unfortunate consequence, though it may be possible to "bend" the rules in translation processes to remove a limited amount of biomass for energy production in the form of invasive or non-endemic species. The latter may also be improved under The Energy Transition for the Green Growth (Ministère 2015), which should involve greater powers for regions, for example the ability to tender out new renewable energy projects when the region deems necessary. Laws obliging electricity distributors to purchase electricity from renewable sources first, in combination with monetary incentives, led to an explosion of solar power and helped create momentum for renewable energy development on the island and could be used again to kick-start and maintain development. Reunion Island's drive to become an experimental place for energy production has led to mixed results and the island's renewable energy production currently relies on proven methods. The innovative experiments have not truly benefitted the local population, even when they are successful, as the ocean thermal energy conversion case illustrates. These experimental projects also highlight the EGC's focus on entrepreneurial translations and the current lack of public inclusion on project development. That said, these types of experiments need to occur somewhere in order for marine energy development to advance, and may one day pay off for Reunion Island; and they have already provided a solution for the IES of other insular communities.

\section{Conclusions}

Reunion Island's quest for energy autonomy presents an interesting case for regional, national, EU and insular community based energy governance processes. The EGC is the most important governance tool for renewable energy development and the main stakeholder within the translating assemblage on the island. It works under the French NREAP and has translated the plan in the SRCAE with the aim of becoming self-sufficient. This translation goes far beyond French aims due to local peculiarities and potentials that frame Reunion Island as a translation loop, and represents one possible way to create added value for the island (e.g. bioenergy, stop financial drainage for fossil fuels). Yet questions remain surrounding EDF's position on the strategic committee and its consequently prominent role in translation processes on Reunion Island, resulting in the slowing down of certain potential innovations and decentralisation of the distribution network. While opening the market to real competition may not bring financial gains for customers (Weisser 2004), it might speed up the development of alternative solutions and path creation as it opens up translation processes to consider alternative solutions that could move Reunion Island towards a more decentralised and participatory energy system to achieve energy autonomy. The EGC must also look seriously at the current political ambition to sell the island as an innovative place since it has not really reaped the rewards of its investments.

The effects of national energy policy translation illustrate that they have both promoted and restricted certain forms of renewable energy development on Reunion Island. Solar energy experienced a boom thanks to the obligation of energy distributors to purchase electricity from renewable sources, but the subsequent moratorium caused the blossoming industry to stagnate, while environmental protection laws currently hinder biomass and wind energy development. These and the other aspects mentioned above raise the question of whether or not the design of EU and French national policies and their corresponding translations are open enough to enable 
a regional translation process that caters to the needs of the island as perceived by regional actors and its particular environment. Thus far, it seems they are not. In particular, the role of the CRE has failed regional renewable energy development and restricted translation capabilities to a narrow frame, though this may change with The Energy Transition for the Green Growth (Ministère 2015).

The study shows that the question of policy mobility and translation concerning the particularities of the policy target (e.g. insular communities) as portrayed above are important when aiming to understand and implement supra-national and national policy approaches. Thus, to evaluate the applicability and development of solutions, such as the EGC in locations with an IES and elsewhere, we must go beyond potential calculations, quantitative socio-economic surveys and policy transfer treating localities as unproblematic recipients of policy. This includes integrating the socio-economic fabric that reproduces governance structures and translating assemblages in implementation sites. The fact that national policy translation frequently restricts the direction of Reunion Island's energy transformation provides the EGC, as a governance tool, with many challenges to translate EU and national energy policy in a way that meaningfully addresses the multiple local expectations and fosters local development. Thus, to understand and eventually adjust current developments and local choices, the local peculiarities that underlie these translation processes must be understood. By treating and evaluating the processes shaping Reunion Island as a translation loop of EU and national energy policy, this study has contributed to this need.

\section{Notes}

${ }^{1}$ Bagasse refers to the stalks of sugar cane which, after being used for sugar and rum production, may be burned to produce electricity.

${ }^{2}$ Loi du 10 février 2000 relative à la modernisation et au développement du service public de l'électricité

${ }^{3}$ Loi n $86-2$ du 3 janvier 1986 relative à l'aménagement, la protection et la mise en valeur du littoral

\section{Acknowledgements}

This research has been conducted with the support of the Academy of Finland Project (No. 14878) "Contesting Bioenergy Governance" at the University of Eastern Finland. We are thankful to the editor at Fennia and to the anonymous reviewers for their helpful comments.

\section{References}

Akuo (2015) Et si une centrale photovoltaïque développait durablement nos territoires? < http://www. akuoenergy.com/bardzour> 26.10.2015.

Albioma (2015) Acquisition de 14 Centrales Photovoltaïques à La Réunion. <http://www.albioma.com/ wp-content/uploads/2015/04/albioma_cp_20150414.pdf> 6.10.2015.

Albrecht, M. (2010) Transboundary governance of the Curonian Spit World Heritage Site. Journal of Environmental Planning and Management 53(6) 725-742.

https://doi.org/10.1080/09640568.2010.488105

Albrecht, M. (2015) Enlightenment in Norway's oil shadow? Governance assemblages of a woodbased district heating network in Norway's' inland region. Journal of Environmental Policy and Planning 17(3) 381-401. https://doi.org/10.1080/1523908X.2014.964851

Albrecht, M. (2017) The role of translation loops in policy mutation processes: State designed bioenergy regions in Germany. Environment and Planning C: Government and Policy (in press). https://doi.org/10.1177/0263774X16669354

Albrecht, M. \& Trishkin, M. (2017) Bioenergy policies: a tool for regional development and source of local conflicts. In Karelian Research Center (ed.) Ecological and economic problems of development of regions and countries (sustainable development/management of natural resources), Proceedings of the 14th International Conference of the Russian Society for Ecological Economics, 3.-7.6.2017, 150156. Karelian Research Center, Petrozavodsk, Russia.

Allen, J. (2011) Topological twists: power's shaping geographies. Dialogues in Human Geography 1(3) 283-298. https://doi.org/10.1177/2043820611421546 
Article 10 (2000) Loi n²000-108. (2000) Loi n²000-108 du 10 février 2000 relative à la modernisation et au développement du service public de l'électricité. <http://legifrance.gouv.fr/affichTexte.do?cid Texte $=$ LEGITEXTO00005629085\&dateTexte $=201510>26.10 .2015$.

Bagci, B. (2009) Towards a zero energy island. Renewable Energy 34 784-789. https://doi.org/10.1016/j.renene.2008.04.027

Blumer, Y. B., Stauffacher, M., Lang, D. J., Hayashi, K. \& Uchida, S. (2013) Non-technical success factors for bioenergy project-learning from a multiple case study in Japan. Energy Policy 60 386-395. https://doi.org/10.1016/j.enpol.2013.05.075

Bulkeley, H. (2005) Reconfiguring environmental governance: towards a politics of scales and networks. Political Geography 24 875-902. https://doi.org/10.1016/j.polgeo.2005.07.002

Clarke, J., Bainton, D., Lendvai, N. \& Stubbs, P. (2015) Making policy move: towards a politics of translation and assemblage. Policy Press, Bristol, UK.

CMS (2014) L'assouplissement par la loi du 15 avril 2013 du cadre juridique de l'implantation des éoliennes terrestes en zone littorale dans les department d'outre-mer, 03.06.2014.<http://wWw.cms-bfl.com/ newsmedia/publicationdetail/pages/default.aspx?publicationguid $=96 \mathrm{f} 8 \mathrm{cdd} 8 \mathrm{-}-8 \mathrm{a} 2 \mathrm{f}-4 \mathrm{~d} 4 \mathrm{~d}-\mathrm{-}$-93ba19babdc6d8d5> 26.10.2015.

Coastal Law (1986) Loi Loi nº 86-2 du 3 janvier 1986 relative à l'aménagement, la protection et la mise en valeur du littoral.

Cohen, A. \& McCarthy, J. (2015) Reviewing rescaling: Strengthening the case for environmental considerations.ProgressinHumanGeography39(1)3-25.https://doi.org/10.1177/0309132514521483

CRE (2015) Commission de Régulation de l'Énergie. <www.cre.frlen> 26.10.2015.

Culpepper, P. (2006) Capitalism, coordination, and economic change: The French political economy since 1985. In Culpepper, P., Hall, P. \& Palier, B. (eds.) Changing France: the politics that markets make, 29-49. Palgrave Macmillan, Houndmills, Basingstoke, Hampshire, UK.

DCNS (2014) Ocean thermal energy conversion. <http://en.densgroup.com/produit/ocean-thermalenergy-conversion/> 26.10.2015.

Dolowitz, D. P. \& Marsh, D. (1996) Who learns what from whom? A review of the policy transfer literature. Political Studies 44(2) 343-357. https://doi.org/10.1111/j.1467-9248.1996.tb00334.x

Dolowitz, D. P. \& Marsh, D. (2000) Learning from abroad: The role of policy transfer in contemporary policy-making. Governance: An International Journal of Policy and Administration 13(1) 5-24. https://doi.org/10.1111/0952-1895.00121

Diagne, H. M., David, M., Lauret, P. \& Boland, J. (2012) Solar irradiation forecasting: state-of-the-art and proposition for future developments for small-scale insular grids. Proceedings of the World Renewable Energy Forum 2012 (WREF 2012). Denver, USA. <https://hal.inria.fr/hal-00918150/document> 1.9.2017.

Duic, N., Lerer, M. \& da Graça Carvalho, M. (2003) Increasing the supply of renewable energy sources in island energy systems. International Journal of Sustainable Energy 23(4) 177-186. https://doi.org/10.1080/01425910412331290760

EC (2012) Energy roadmap 2050. European Commission, Brussels.

EC (2015) National action plans. European Commission, Brussels. <https://ec.europa.eu/energy/en/ topics/renewable-energy/national-action-plans> 27.10.2015.

Engstrom, D. F. (2012) Coralling capture. Harvard Journal of Law \& Public Policy 36(1) 31-39.

Garric, A. (2010) “La Grenelle de l'environnement est devenu un simple label". Le Monde 2.11.2010. <http://www.lemonde.fr/planete/article/2010/11/02/le-grenelle-de-l-environnement-est-devenu-unsimple-label $14341663244 . h t m />26.10 .2015$.

Garud, R., Kumaraswamy, A. \& Karnøe, P. (2010) Path dependence or path creation? Journal of Management Studies 47(4) 760-774. https://doi.org/10.1111/j.1467-6486.2009.00914.x

Hage, J. (2006) Institutional change and societal change: The impact of knowledge transformations. In Hage, J. \& Meeus, M. (eds.) Innovation, science, and institutional change, 465-482. Oxford University Press, Oxford.

INSEE (2015) Réunion. <http://www.insee.fr/fr/regions/reunion/> 5.11.2015.

Kortelainen, J. \& Albrecht, M. (2014) Translation loops and shifting rationalities of transnational bioenergy governance. In Stripple, J. \& Bulkeley, H. (eds.) Governing the climate: new approaches to rationality, power and politics, 144-159. Cambridge University Press, Cambridge.

La P'tite Gazette (2004) EDF Garde Son Monopole Dans Les DOM. <http://www.la-ptite-gazette.com/ Archive-Actualites-la-Reunion/article/Edf-garde-son-monopole-dans-les-dom-1533.htm/> 26.10.2015.

Linfo (2013) Fin du projet GERRI - réussir l'innovation. Linfo.re 3.04.2013. <http://www.linfo.re/lareunion/economie/fin-du-projet-gerri-reussir-l-innovation> 26.10.2015. 
Marquardt, J. (2015) The politics of energy and development: aid diversification in the Philippines. Energy Research \& Social Sciences 10 259-272. https://doi.org/10.1016/j.erss.2015.07.013

Massey, D. (2005) For space. Sage Publications, London.

McCann, E. (2013) Policy boosterism, policy mobilities, and the extrospective city. Urban Geography 34(1) 5-29. https://doi.org/10.1080/02723638.2013.778627

McCann, E. \&Ward, K. (2012) Policy assemblages, mobilities and mutations: towards a multidisciplinary conversation. PoliticalStudies Review 10325-332. https://doi.org/10.1111/j.1478-9302.2012.00276.x

Michalena, E. \& Angeon, V. (2009) Local challenges in the promotion of renewable energy sources: the case of Crete. Energy Policy 37 2018-2026. https://doi.org/10.1016/j.enpol.2009.01.047

Ministère de L'Écologie, du Développement Durable et de L'Énergie (2009) Le projet Réunion 2030 GERRI. Le Point Sur $n^{\circ} 28$ octobre 2009. <http://www.developpement-durable.gouv.fr/IMG/pdf/LPS GERRI-V3 cle57e5e6-1 1.pdf> 26.10.2015.

Ministère de L'Écologie, du Développement Durable et de L'Énergie (2012) La genèse du Grenelle de I'envionnement, 28.12.2012. <http://Www.developpement-durable.gouv.fr/La-genese-du-Grenelle-de-l. html> 26.10.2015.

Ministère de L'Écologie, du Développement Durable et de L'Énergie (2015) La Transition Énergétique Pour La Croissance Verte. <www. developpement-durable.gouv.fr/-La-transition-energetique-pour-la-. html> 26.10.2015.

MrMondalisation (2015) Nouvelle route du littoral: un projet pharaonique sous les tropiques. MrMondalisation, 19.8.2015. <https://mrmondialisation.org/nouvelle-route-du-littoral-un-projetpharaonique-sous-les-tropiques/> 6.10.2015.

Murdoch, J. (2006) Post-structuralist geography: a guide to relational space. SAGE, London.

Nybakk, E., Niskanen, A., Bajric, F., Duduman, G., Feliciano, D. \& Jablonski, K. (2011) Innovation in the wood bio-energy sector in Europe. In Weiss, G., Pettenella, D., Ollonqvist, P. \& Slee, B. (eds.) Innovation in forestry: Territorial and value chain relationships, 254-275. CABI, Wallingford. https://doi.org/10.1079/9781845936891.0254

Oikonomon, E. K., Kilias, V., Goumas, A., Rigopoulus, A., Karakatsani, E., Damasiotis, M., Papastefanakis, D. \& Marini, N. (2009) Renewable energy sources (RES) projects and their barriers on a regional scale: the case study of wind parks in the Dodecanese islands, Greece. Energy Policy $374874-$ 4883. https://doi.org/10.1016/j.enpol.2009.06.050

Parc National de La Réunion (2007) Les Actions Interdites. <http://www.reunion-parcnational.fr/?Lesactions-interdites> 26.10.2015.

Peck, J. (2011) Geographies of policy. From transfer-diffusion to mobility-mutation. Progress in Human Geography 35(6) 773-797. https://doi.org/10.1177/0309132510394010

Peck, J. \& Theodore, N. (2015) Fast policy: experimental statecraft at the threshold of neoliberalism. University of Minnesota Press, Minneapolis. https://doi.org/10.5749/minnesota/9780816677306.001.0001

Pierson, P. \& Skocpol, T. (2002) Historical institutionalism in contemporary political science. In Katznelson, I. \& Milner, H. V. (eds.) Political science: the state of the discipline, 693-721 W.W. Norton \& Company, New York.

Praene, J. P., David, M., Sinama, F., Morau, D. \& Marc, O. (2012) Renewable energy: progressing towards a net zero energy island, the case of Reunion Island. Renewable and Sustainable Energy Reviews 16 426-442. https://doi.org/10.1016/j.rser.2011.08.007

RED (2009) Directive 2009/28/EC of the European Parliament and the Council of 23 April 2009 on the promotion of the use of energy from renewable sources and amending and subsequently repealing Directives 2001/77/EC and 2003/30/EC.

Reporterre (2015) A La Réunion, manifestation massive contre le projet fou d'autoroute sur pilotis. Reporterre. 8.6.2015. <http://wWw. reporterre.net/spip.php?page=redirect\&id article=7635> 6.10.2015.

Royer, J. (2015) Case study: CETO La Reunion. <http://coastalenergyandenvironment.web.unc.edu/ ocean-energy-generating-technologies/wave-energy/case-study-ceto-la-reunion/> 26.10.2015.

Sabatier, D., Martine, J. F., Chiroleu, F., Rousse, C., Letourmy, P., Van Antwerpen, R., Gabrielle, B. \& Ney, B. (2015) Optimization of sugarcane farming as a multipurpose crop for energy and food production. GCB Bioenergy 7 40-56. https://doi.org/10.1111/gcbb.12133

Sarrica, M., Brondi, S., Cottone, P. \& Mazzana, B. M. (2016) One, no one, one hundred thousand energy transitions in Europe: the quest for a cultural approach. Energy Research \& Social Sciences 13 1-14. https://doi.org/10.1016/j.erss.2015.12.019

Saudemont, E. (2015) Première mondiale à la Réunion: un projet SWAC de $40 \mathrm{MW}$ froid. Pétrole \& Gaz. 25.05.2015. <http://Www.petrole-et-gaz.fr/premiere-mondiale-a-la-reunion-un-projet-swac-de40-mw-froid-4433/> 26.10.2015. 
Sawatzky, M. (2013) Voices in the woods: A study of forest use in Eastern Manitoba. Dissertations in Social Sciences and Business Studies, no 55. Publications of the University of Eastern Finland, Joensuu.

Sovacool, B. K. (2014) What are we doing here? Analyzing 15 years of energy scholarship and proposing a social science research agenda. Energy Research \& Social Sciences 1 1-29. https://doi.org/10.1016/j.erss.2014.02.003

SRCAE (2013) Schéma Régional Climat Air Énergie de la Réunion. Préfet de la Réunion, Region Réunion, ADEME. <http://www.reunion.developpement-durable.gouv.fr/IMG/pdf/schema regional climat ai energie 974 cle2c5f8e.pdf> 1.9.2017.

Sugiura, S., Yamaura, Y., Tsuru, T., Goto, H., Hasegawa, M., Makihara, H. \& Makino, S. (2009) Beetle responses to artificial gaps in an oceanic island forest: implications for invasive tree management to conserve endemic species diversity. Biodiversity Conservation 18 2101-2118. https://doi.org/10.1007/s10531-009-9575-9

UNEP (2014) Emerging issues for small island developing states: Results of the UNEP foresight process. UNEP, Nairobi.

van Waarden, F. \& Oosterwijk, H. (2006) Turning tracks? Path dependency, technological paradigm shifts, and organizational and institutional change. In Hage, J. \& Meeus, M. (eds.) Innovation, science, and institutional change, 443-464. Oxford University Press, Oxford.

Weisser, D. (2004) Power sector reform in small island developing states: What role for renewable energy technologies? Renewable \& Sustainable Energy Reviews 8 101-127. https://doi.org/10.1016/j.rser.2003.10.002

Whiteside, K. H., Boy, D. \& Bourg, D. (2010) France's 'Grenelle de l'environnement': openings and closures in ecological democracy. Environmental Politics 19(3) 449-467. https://doi.org/10.1080/09644011003690930 